\title{
Global System in a Changing Social Reality: How to Rethink and to Study It
}

\author{
Antonio Sánchez-Bayón \\ School of Law \& Economics, Camilo José Cela University, Madrid, Spain \\ Email: asbayon@ucjc.edu \\ Received 23 June 2014; revised 21 July 2014; accepted 15 August 2014 \\ Copyright (C) 2014 by author and Scientific Research Publishing Inc. \\ This work is licensed under the Creative Commons Attribution International License (CC BY). \\ http://creativecommons.org/licenses/by/4.0/ \\ c) (i) Open Access
}

\begin{abstract}
This paper pretends to show the new global reality and its improving paradigm in Social Sciences. Under the globalization has emerged a lot kind of crisis, specially, in political, legal and economic areas. It is offered a model to rethink, in a holistic way, the new social reality mentioned. Also, the paper explains how to study the issue, beyond the International Law \& Affairs approaches, according to Global studies way.
\end{abstract}

\section{Keywords}

Global Law \& Politics, Holistic, Globalization, Social Reality, International Relations/Affairs, International Organizations/Institutions

\section{Introduction: Rethinking the Social Reality and Its Paradigm}

Social reality is our environment of development: human relations according to rules and institutions of power and order, codes of communication, symbols, etc. With the globalization everything is in crisis now, because we are moving to other way of life and social context. For this reason it is so important to rethink the social factors and the paradigm. The factors are those variables that condition the march of social reality and with it, the perception that we have of the same, which is the paradigm. Then, a paradigm is like the intellectual glasses that we use to see the reality, which implies having to recognize from the outset that: a) our vision is deficient, and b) it requires periodic adjusting, in case it has changed. And that is how it is, because a paradigm is only as valid as the extent it permits to solve the problems that take place in reality, but if it does not fulfil such mission, this implies that its time has passed and one should think of adjusting the lens or making a new one through which to see the reality better. The reality of the sovereign political communities and its evolution, see references, it dependences of some forces, particularly, the dialectic between the local and the universal forces: polis $v$. league, village v. kingdom, State v. Christianity, etc. Exactly in the last dialectical category is where the entanglement lies, cause of today's increase in short-sightedness. Once Christianity disintegrated with the fall of the Empire 
and the Papacy, being substituted by particular Churches and States), matter that is juridical typified in the Peace of Westphalia, 1648 (Westphalian order - the begging of the next orders, built around the State), and the type of International Law that begins to gain ever greater importance, looking to extend not only over its space, but also that of any type of supra or transnational community-in this way the vocation of potency is initiated, reaching its zenith with nineteenth century colonialism. The order of Westphalia-Vienna, based in the alliances between the great dynasties of imperial vocation (e.g., Spain, Russia, Austro-Hungary), begins to crumble with the end of the century State-conferences, and its end is complete with the First World War (1914-1919). The next order, Versailles-Yalta/Potsdam, it is based in a heterogeneous international society, and it runs until the end of the Cold War. Since the 1990s, it has been questioned whether the betrayed spirit of the order of San Francisco and the UN should be recovered, giving way to an authentic and sustainable international community (e.g. Speech by President Bush, 1990), or better yet, of global village_even, Humanity's Community or Type I Civilization ${ }^{1}$. The thing is that, for a decade, reigns a sort of artificial euphoria, circumscribed to developed countries, reason why this time came to be termed as the order of Wall Street-Hollywood, reaching its end with the terrorist attacks of September 11, 2001, causing a rupture of the tendency and, even, a regression to the coldest moments of the Cold War, only that now it is the War on Terror(ism) of planetary reach and without a clear enemy, who in addition can attack at home- one of the most used expressions by the George W. Bush Administration. Today, a decade later, it seems that we return once again to the Spirit of San Francisco-now also Rome, because of the International Criminal Court and the example of integration of the European Union, and one also begins to hear the notion of global village (of the legal humanist texts), but there are also coexist cynical expressions of the global factory type (World scale real economy directed by: World Trade Organization, Organization of Economic Co-Operation Development, European Union, Mercosur, Alca, Free Trade Agreements, etc.); Global Las Vegas (a financial World of stock brokers supervised by: Central Banks and the World Bank Group, along with the International Monetary Fund); the global polis (an attempt at World governance without a concentrated government, but through a network of international organizations and world forums); a global apartheid (because the Asian-Pacific, Western European and North American triad hold power and the rest of the world is dependent- even within these spheres there are wide degrees of inequality), etc. In essence, such denominational variety shows that there is still no one dominant conception or shared vision of the whole, for which reason one cannot talk about one single globalization, but of a variety, which require of certain degree of consensus. And it is that the ongoing process of globalization does not have to lead to a positive future of harmony and solidarity, but it could become in a brutal asymmetry—rather than closing gaps, polarizing positions—just like an unjust fragmentation - without wealth redistribution, and closer to the Toyota sector model, where one does not work for the good of humanity, but for the benefit of corporations. The point is, since we live a time of transition, between an age that agonizes, of the monopolist nation-State, with its paradigm of the formalist positivist (Statutes/Statutory Law), and another that is being born, of pluralism of the community or global village, with its paradigm of fuzzy and holistic positivist system, which promotes an internet of solidarities-rather than the current unequal exchange, which brings Law closer to force (of the great powers and their imposition of game rules) than to reason, then, one understands the importance of tackling the serious study of Global Law².

\footnotetext{
${ }^{1}$ Current hypothesis comes from the soviet astrophysicist Kardashev (celebrated member of the Academy of the Sciences of the Union of Soviet Socialist Republics), according to which, as far as the world's joint and several interdependence is assumed, then, we will have reached a rank of type I civilization, which is the one that is able to act globally. Type II civilizations are the ones that achieve operations to the extent of their solar system. Type III civilizations are those that have the capability to cover their whole galaxy (Sánchez-Bayón, 2012b, 2012c, 2013).

${ }^{2}$ Keys of the new world order (Sánchez-Bayón, 2011a, 2011b, 2012b, 2012c, 2013): a) The nation(al)-State crisis: dismemberment of countries and awakening of national minorities and regionalisms (e.g., the dissolution of Czechoslovakia, fragmentation of the USSR into the Russian Federation, the Eastern Baltic States, etc; devastation of Yugoslavia); loss of economic sovereignty (transferred to international organizations and creation of free trade areas, custom and monetary unions, multinationals with a network of offices and budgets larger than those of many governments); impossibility of security and individual defence, but rather it must be collective because of the cost of cyber warfare; foreign policy based on interdependent solidarity; outsourcing of corporate labour (Toyota's model of production and tax havens); transnational crime (mafia and cells in diverse countries); crisis of the welfare State (the inversion of the population pyramid, more needs than resources); global environmental threats (the ozone layer, global warming, climate change); awakening of civil society through NGOs and world social forums (movements invited to UN organized world forums and conferences). b) The hatching of globalization: end of the Cold War (fall of the Berlin Wall 1989, German reunification 1990-1994, the emergence of new republics 1991), Information and Communication Technology advances (satellites for civil use, private satellite TV, mobile phones); massive incorporation of home computers and internet access; charter and low-cost air travel; increase in financial markets and instruments-a fivefold increase in operations in the real economy: in number and in volume of money managed; new economy based in information and communication technology: dot com businesses and International Organizations (reactivation of the UN in human rights- the Gulf War 1990-1991, Central African Wars 1990s and peace missions around the whole world - and education in human rights; the signing of NAFTA and Mercosur in 1991, adoption of the Treaty of the European Union in 1992, and the consolidation of the GATT into the WTO since 1996, etc.).
} 
The matter regarding the ordering of a new age of openness, because of the changes in the supranational community, is not something new and proper of our time-rather it is a result of a cyclical phenomenon. Nevertheless, our most immediate, direct inheritance comes from the $18^{\text {th }}$ Century's Enlightment (from authors such as Locke, Vattel, Wolff, or Kant), who claimed then a scientific and practical Right of Peoples, to consolidate a perpetual peace and a cosmopolitan community through commerce between peoples. The problem then was that it was only a game of the elites, rather than a tangible reality, in contrast to the current situation, because thanks to the information and communications technology, it is possible to materialize these ideals and social demands, giving way to a true process of globalization.

\section{Empiric Frame: What Is Globalization?}

Neither apocalyptic nor integrated (as Eco said in the 60s), yes glocal... In other publications (of this author), it was said about it: "Globalization is not homogeneous and done; it is not a conglomeration understood as heaven or hell. It is a transformation process of the social reality. It does not result in something malignant, that comes to make vulnerable the individual and social guaranties it has reached, but that rather represents an opportunity to broaden our knowledge of the march of the World, and in such a way, be able to reformulate the rules of the game for the new world arrangement. This type of process of opening of the known world takes places cyclically, allowing us to extend our borders, and with them, the vision that we have of ourselves and of our (social and natural) surroundings. Serving as expansionary examples, promoting the West, ${ }^{3}$ the case of the Greco-Roman ekumene (reaching the British isles) as well as the Hispanic new world (reaching all the way to America), are instances of how much the Mediterranean peoples have to say, thanks to their colossal and extrovert culture, that is, its universal humanism and its integrating officialdom: its Catholicism. ${ }^{4}$ The problem, of clash and fragmentation, arrives with mercantilism and the nation-State, that under the direction of the Nordic barbarians (including the Anglo-Saxons), proceeded to substitute economy for culture, ideology for religion, consumerism for happiness, utopias or no place for illusion..., so that the current paradoxical situation is not become consolidated, in which globalization is reduced to the postulates of the Nordic peoples, who pretend to make the world a faked planetary/World-State, at their mercy: for their interests but without the responsibilities, based on coercion without justice, where it is possible to transplant their rules of excessive development, through a deregulation of individual and social guarantees, giving instead a qualified cover to capital, goods, and services - which then reach the same or greater recognition, protection and freedom of movement than peoples themselves, who should be the ones to enjoy them; then, it will be agreed, another vision is necessary. A call for global reflection that serves for local action: the glocal requirement. Among the voices which should be heard because it has much to say about the attainment of a better world for all, the syncretic Iberian-American voice stands out, because this is a synonym for culture and (of universal) humanism. But, of what does it consist? It proposes some clues for its (re)-discovery, but first we need to purge it of fallacies, so that its contextualization in globalization may be easier". Of all of these ideas mentioned, the one most interesting for reflection and to which we pretend to call to our student's attention is globalization (there no longer are planetary barriers, thanks to information and communication technologies) and the global (everything integrated as a network); and if a further turning of the screw is admitted, also the notion of "glocal", in regard to thinking global and acting local, although it equally implies the processes in which globalization has been localized and vice versa. Before continuing in a type of reflection tending towards $21^{\text {st }}$ Century Social Philosophy (juridical, political and moral), it returns to the empirical of Comparative Law — as we have just seen and as it has guided us up to this point, and the next great question.

\section{Overview: Does a Current Common Law (and Politics) Exist?}

Those are anchored with the past paradigm, and they cannot recognize-because they do not want, or do not

\footnotetext{
3“Always to the West” (typical sentence), because the East is well known (it conceived as full and untrustworthy), whereas the western frontier offers so many vast territories — supposedly_almost empty and uncharted. That has been the belief that has promoted the advance in that direction, because if the West supposes declaiming, where the sun sets, in reality, the impetus of going beyond supposes a longing of resurrection: the illusion of a better World.

${ }^{4}$ Catholicism, just as it was fixed by the Hispanic Emperor Theodosius in the Edict of Thessalonica of 380 (Codicen Theodosianum, Librum $X V I$ ), and that since the 6th century papal literature promoted the impulse the regime of the Council, which in the Iberian Peninsula served to incentivize the Reconquista/Reconquest, even granting to the Trastamara dynasties the title of "Catholic Monarchs", so that they could continue their conquest and evangelizing mission in the New World — where what matter were the souls and not the resources and lands, in contrast to the Nordic colonization.
} 
know how, to leave their comfort zone-that the same is vanishing, and they are incapable of appreciating the coming situation —even to the point of denying it, cause it does not fit their paradigm—provoking with this a greater distancing between theory and practice, between the current Jurisprudence/Juridical Sciences Schools and the day-to-day work of legal operators. This kind of School—until this date abundant in Continental-Europe -has advocated for recognizing an International Law, at the mercy only of States' interests and their formal positivism - thus, a sort of external State Law of the Hegelian type. In fact, it does not even include all States, but only the great powers, in whose hands international organizations are as well. And they only recognize that International Law recognized in binding instruments (coercion), and if need be (duress). In this way, it is possible to explain that this School (former paradigm) speaks of hard-law, and just it glosses over International Law according to academic disputes, which distinguish and make independent International Law from international relations, International Public Law from Private International Law, etc. Recognizing such closed mindedness and distancing from the reality in progress, it supports by this paper the evaluation of the principles, comparing diachronic and synchronic, to ascertain where the deviation took place and how to recover the right path, not so much of the mentioned enlightened thinkers, with their elitist games of geopolitics, but as a response to the world demands in constant flux, because of the initial transition espoused.

In these pages we are convinced-from over a decade of field and office work-that there exists such Common Law of Globalization, only that it is in course-still in a formulation and implementation phase. Just as in past times, when there was a superior community coalesced by values and common projects, as happened with Empires, such as the Roman and its Common Law, or the Spanish and its New Law, even Christianity with its university network and its common law, then, What supranational community would be necessary to be able to talk today of a Common Law? To answer it is convenient to begin by understanding the system and its sources, and then follow up with its nature and topic. That is the plan of the next few pages.

\section{Building the System: (Neo)utrumque ius or Global Law?}

The issue about the name is not trivial, because it entails a whole ontological, epistemological, and axiological charge - this paper is in favour of the most representative names/denominations, each one from its juridical-political culture, but as shall not escape the seasoned reader, there are many more, much more, that are managed and compete to become the main one: Global Law, International Law, Law of Humanity, Transnational Law, etc. ${ }^{5}$ Thus, giving a Latin denomination, in the manner of a neologism - that pretends to inherit from one of the most prestigious Western juridical traditions, as is the Roman Law, or bestowing an English title - the new Latin of the third millennium, with a more practical and true to reality vocation, without need of any references, considerably changes the subject's progress and object of study. And it is that, if (neo)utrumque ius [new Law of ones and others] is employed, it is then understood that academics ought to be the protagonists, being capable of joining the influences of the diverse world juridical families (interacting in the heart of international organizations); there that this be the preferred route of continental Europeans and, despite being related to one or the other Law, with more emphasis in that, since the Greek and the Latin are united to form the neologism, it is evident that they procure to bring close the ideas to their Civil or Continental European Law (CEL), ${ }^{6}$ giving a more deductive and dogmatic character to that new Common Law in course. In contrast, choosing Global Law is to give priority to the practice of Law, to the inductive study of the responses that have been developed before the problems of reality, for which reason judges will place the emphasis (whom will use Comparative Law with ever greater frequency to support their arguments). Because of personal reasons, these authors prefer to not elect,

\footnotetext{
${ }^{5}$ Other worthy references — of converts (who abandoned the formalist state positivism)—-has been the one of the Nomos of the Earth Schmitt, the judicial globalism of Kelsen, and the global order of Bobbio et al. (Sánchez-Bayón, 2009, 2011b, 2012c).

${ }^{6}$ Reference is made to the juridical family that covers most of the central European parliamentary and Mediterranean systems (originally influencing in Latin Americans, who only later reach their singularity), where a deductive vision prevails (that serves as model and that is abstract), besides of a normative view (completely concerned with what ought to be and its hierarchization, which explains the defence of the norm's textualism), conferring - in the end-greater importance to laws as source of Law. Also, this explains the preference for written law, of a technical and legal character, and authorized by the Administrations under the pretext of the best welfare of the people. One error to underscore in regard to CEL is the confusion with respect to its denomination as civil law, because its "civil" quality is not because of the pre-eminence of private Law, but because of its non-religious character-remember the other denomination promoted by Hobbes: political v ecclesiastical; this denomination responds to the impulse desired by the public powers of the nineteenth century nation-state. Another habitual confusion is to think that CEL is a direct beneficiary of Roman Law, as is, when in reality it is a completely new type of Law, of scientific character, promoted by academics and the Administration, through statutory and regulatory rules. Due to the vestiges of Absolutism and the influence of communitarian ideologies, CEL has been configured as a Law that is eminently public and promoter of the social welfare state.
} 
because we feel ourselves beneficiary of both Laws: on the one hand we are well familiarized with the Late European Medieval utrumque ius through the Continental European, and on the other, in the USA., we had the opportunity to enjoy of NAIL movement (New Approaches on International Law), with its heart at Harvard, from where all other universities of the world have coordinated (for example, Latin Americans such as Univ. Andes-Colombia, or European ones, such as Univ. Complutense-Spain). Hence, due to intellectual reasons, it is difficult to choose in favour of one over the other. Following the line we have traced, this work does not intend to detain itself with disjunctive dilemmas, but to foster conjunctive copulations that permit the diffuse holistic system (DHS), ${ }^{7}$ then, despite the necessary precisions, since this is an initial advisory and pragmatic work, we will use both denominations as synonyms: (neo)utrumque ius and Global Law.

It remains to be emphasized that, the wielding of this expression, it does not only permits to being making concrete the study we intend to undertake, but we also begin to unveil the type of focus, methodology and topic we are to manage. Likewise, it allows us to inquire about the past, make a valuation of the present, and forecast the immediate future: why such a thing? Simply, because it is not the first time that something like this happens. This same problem was already lived by the cited eighteenth century Enlightment thinkers, who found themselves in the tessitura of choosing between novo ius gentium/universalis ius o International Law-a barbarism attributed to Bentham in the end winning this latter denomination, and eclipsing the other, because the continental Europeans, rejected their own proposal, to reformulate the Anglo-Saxon one of International Law [Law of Peoples] and to give it a Statutory Law [legislation] look between nation-States (in their assembly headquarters, as they considered international organizations), that is to say, the Law of the treaties between first class States, which are the ones that sign the creation of the Society/League of Nations at the beginning of the twentieth century.

\subsection{Fundamentals I: Principles of Global Law (GL)}

If International Law correspond-as we have just explained—with the lapsed paradigm of State formalism, Global Law advocates for a systemic holistic and fuzzy net paradigm, whose articulating principles are, besides the generic type of institutional reality, of unity, of wholeness, of three-dimensionality, of transitivity, of the holistic and fuzzy et al.; and the very specific Law of International Organization-specially, the UN's statements: arts. 1 \& 2 of the San Francisco Charter, and the multiple Resolutions, from Res. 2625 of 1970 about the princeples of International Law, in addition to Res. 42/149 of 1987 about the Progressive development of the princeples and norms of International Law relating to the new international economic order, up to the Millennium Declaration (2000), ${ }^{8}$ there are some key prima principia to consider, as that of subjectivity, solidarity, plurality, joint agreement, etc. Also we ought to consider other sources, as the geopolitical pronouncements-beyond the

\footnotetext{
${ }^{7}$ The peculiarity of the system that is presented here hails from the observance of the social order in favour of the holistic \& fuzzy net, taking from what since decades has been done in the Natural Sciences, especially in Physics, with its $m$ theory of integration. To avoid that an excessively formal logic conceptualization leads to a monolithic dogmatism, as we have experienced in the Juridical Sciences, and whose ultimate resulting episode has been formalist state positivism, we equally attend to a symbolic-logic, flexible, and progressive, because its metaphors so plastic are thought to favour not only the adhesion of the administrative elites and their technical understanding, but to also achieve the implication of the great public and incorporate its notion of justice. A holistic and fuzzy net system, for its flexible, harmonizing vocation (in the manner of an amalgam or uniting network of networks), avoiding an intellectual sclerotization, to serve oneself of organizing patterns on the net, in a dynamic and nonlinear manner, without incurring in crystallized formulas, for closed models of the exclusive and excluding type. From there that, in the manner of a puzzle, a metaphor that should not be a surprise if one takes into account the ones in vogue in the Anglo-Saxon world, such as the melé (just as we shall later clarify), an attempt to conveniently interlock the tradition with the required eventualities, looking for the adequate hooks for it. Only in this manner is a correct integration possible in the bosom of the tradionalist gnosiological statements and the modern epistemological ones- just as we will next clarify, at the same time not losing sight of the march of events of the underlying reality that must be ordered. As a last feature of the DHS is its autopoesis. We make reference in this way to the fact that we consider Law—as well as its underlying human community—as a living reality, that (re)produces itself: the repeating conduct of the people becomes the Law, that reproduces it, either by itself or by the definition that the public powers establish (where the legislative and executive powers regulate and the judicial power interprets, which is another way of reproducing).

${ }^{8}$ Telegraphic sketch of the inspiring principles of the global Community and its (neo)utrumque (universale) ius for the $21^{\text {st }}$ Century (it is about a multi-subjectivity and a plural legal system, such that interdependence and solidarity may be ordered, through the commitment to and consensus of legal rules (Sánchez-Bayón, 2011a, 2011b): 1) traditional (inter-States) ius cogens; a) general/structural principles: equal sovereignty between States, pacific resolution of issues and prohibitions against the use of force, respect to human rights, self-determination of peoples and decolonization; b) erga omnes obligations: good faith; agreements (pacta sunt servanda: consensus, consent and responsibility), reciprocity, respect of the public order (cessation of the illicit, no reiteration and reparation), prevention. 2) Modern ius cogens (International Organizations): a) superior/dynamist values: eco-pacificism, cooperation and sustainable development, democracy and world governance; b) common interests and ends: re-humanization, re-socialization, re-democratization of the international order, promoting interdependent solidarity through an common interest agenda and favours relations and the rule of validation (favor negotii), broaden and deepen relations and law (ius cogens and erga omnes obligations).
} 
general theory of international organizations and its World role-issued by regional organizations (e.g., the European Union \& Solana Declaration of 2003: A Secure Europe in a better World), and the sector ones (e.g., Organization for Security and Co-operation in Europe and the reports from its thematic offices for electoral processes, freedom of press, etc.). And without discussion what it has to say about NGOs in civil society, such as International Amnesty, Human Rights Watch, etc., with their impact in the public opinion of the world. If anything worries States more today, it is not their sovereignty, but their international isolation. From there that they take into account such public opinion.

\subsection{Fundamentals II: Subjects Background}

The defenders of the outdated paradigm of positivist formalism vigorously deny the lessons from History and Philosophy of Law, because it reminds them that their technical discipline-actually — comes from the humanist field: the Law of Nations (ius gentium) proceeds from the Departments of Roman Law and Legal History, whereas the ones of Natural Law (as Pandectists and other movements from $19^{\text {th }}$ Century). Until the middle of the $20^{\text {th }}$ Century, most textbooks on International Law began with a historical and philosophical clarification of its origins and groundings, refuting any arguments against it-those that denied the juridical nature of International Law, considering it just a comitas gentium or courtesy between nations. To correct the deviations still in existence today, we recommend reading the books cited.

\subsection{Fundamentals III: Sources of Law}

It is referred the well-known metaphor of hydraulic source (founts or sources): it is understood as knowledge and production of Law, as well as the power from which it springs and the instruments by which it is channelled. Thus, the sources can be considered-in a brief manner, to avoid repetition-as knowledge (fontes iuris cognoscendi) as well as production (fontes iuris constituendi). With respect to the latter one, in addition it is also necessary to distinguish between the substantive sources (from where the productive power of law emanates) and the formal sources (how power is transmitted and channelled).

Among the sources of knowledge we invite to consult, at the least, the following reference works (as first handbooks) — to provide a philosophical-historical perspective of the development of the reality, the knowledge, and discipline of what today we call International Law, without forgetting its close union with international relations ${ }^{9}$ : Prof. Nussbaum (Nussbaum, 1947—the Spanish edition, by Prof. L. Garcia Arias, Madrid University: there is an Appendix and some Additions, in particular about the Hispanic doctrine on International Law); Prof. Stadtmüller (Stadtmüller, 1951 — the Spanish edition, by Prof. A. Truyol y Serra, Madrid University, who was last Spanish scholar in History and Philosophy of Law and International Law and Relations, with pupils in both areas); Prof. Carrillo Salcedo (Carrillo Salcedo, 1991), who was a Professor and former Judge of the European Court of Human Rights of the Council of Europe-also another Truyol's pupil in doctoral studies, and one of my masters; et al., as part of the stage of the legal awakening of conscience of the civilized world, entering into debates on sovereignty and imperialism, and valuing International Law as German philosophy of 1871-1933, as French sociology or solidarity 1871-1950, and as political realism and force, etc.); against this cited vision, it has to mentioned Habermas’ neomarxist view, denouncing the absence of debate between Kantian idealists and Schmittian realists, besides creating the doubt whether Law is the adequate instrument for international relations or whether it is the unilateral policy of the great superpower; then, according to this latter possibility, world security and the hard nucleus of humanist democracy prevails or is there room for its discussion? et al.

To comprehend the changing reality in course, we invite to consult the prospective works of the already cited International Law Prof. Truyol y Serra (1974) and Carillo Salcedo (1984); and confirming works by professors in other fields, such as Domingo (2008). Other attractive and recent texts are those of Guariglia (2010), Riquelme (2005) Pureza (2002) et al.

In regard to the production sources, in regard to the substantive sources, it is necessary to critically and profoundly reflect about the matter of international subjectivity, that is, about the juridical authentic personality and the legal capacity to contract in today's world — so that we can know in this way who are recognized as subjects of law, and thus capable of producing it: States, international organizations, nations, self-determination movements, individuals, etc. In regard to the formal sources, we remit to article 38 of the Statute of the Permanent

${ }^{9}$ There are chosen editions in English or German, and some Spanish edition, in the way to show the later evolution of the confusions and conflicts among the Chairs in Ibero-American Universities (Sánchez-Bayón, 2009). 
Court of International Justice of the UN, which establishes: treaties, customs, the general principles, and in a special manner jurisprudence and legal commentary-according to the remission to other precepts (in concrete to article 59) and the interpretation that has been made of the document in its entirety, despite that these two last sources are not foundational, they are important in the progress of International Law, in addition to the fact that, despite initially arising between parties, if their importance is great, they can become of erga omnes vocation (if it is seen as supported by other sources: customs and the general principles, codified in a treaty). Between these norms it is necessary to clarify the following heuristic rules (the hierarchy of sources): a) general rule, there is no room to talk about a hierarchy_-despite what formal positivists believe, since the statement (from the cited article 38) is plain: it is only alphabetical, not numerical; b) special rule, the best norm for the case is preferred (e.g., principle of proximity and adequacy); c) exceptional rule, it consists in that, between diverse rules, the ius cogens prevails. Lastly, and almost belabouring the matter, it is possible to distinguish between principal or creating sources (those that directly apply in a matter: customs, treaties, general principles, State unilateral acts and international organizations) and auxiliary or subsidiary sources or of evidence (they do not by themselves create Law, but permit Law to be verified: jurisprudence and legal commentary).

\section{Critical Revision: What Is Wrong with Current International Law?}

It is necessary to clarify, to the reader, how the old Departments of Natural Law and Law of Nations are being replaced for modern ones of International Law, and currently in Global Law chairs. Thus, this paper reviews the terminology and its concepts, unearthing their significance and range.

a) Terminology used and various concepts: despite the traditional denomination of ius gentium based on the reality and common European juridical study (e.g., law of nations, völkerrecht, derecho de gentes, droit des gens, diritto delle genti, direito das gentes, dret de gents, drept gintilor), in contrast, since the end of the $18^{\text {th }}$ century a neologism of reductionist conception, such as International Law, ends up prevailing. The Enlightment authors, finally, before continuing to consume energies inquiring about what the international society ought to be, prefer to concentrate their attention in the relations between the then sovereign nation-States. Therefore, we have passed through the traditionally common names/denominations of the ius gentium type and its ius naturale et gentium revision, up to the predominance of the neologism of International Law. ${ }^{10}$ This new denomination originates from ius inter gentes of the English R. Zouch (1650), who sets the groundings for the translations such as Law of Nations, to the resulting (attributed to J. Bentham). On the other hand, seeing the theoretical divisions among the continental Europeans, these finally renounce to christening but not to providing with content, for which reason they focus their efforts in redefining the neologism, so that it is circumscribed to the relations between States. In good measure, they take from the groundings of the Swiss Vattel, who confuses nation with autonomous political community, and thus State-in his view—even aspired to extend their own neologisms, such as Kant and his Law of States/Derecho de Estados, Hegel and his Foreign State Law/Derecho estatal externo, Miaja de la Muela and his Law among States/Derecho Interestatal, etc. (Sánchez-Bayón, 2011). Throughout the $20^{\text {th }}$ century, the continental Europeans continue with their reformulating penchant of the International Law neologism, looking to distinguish between its public and private sphere. Meanwhile Anglo-Saxons begin to distance themselves from their own neologism, because they being to have difficulties to operate in the reality with dogmatic constructions that are foreign to them, advocating for new nominal propositions: Transnational Law or Global Law.

Therefore, after the expression—still dominant today—of (Public) International Law, the following conceptions operate-setting with it their significance and reach: a) the ideological type-most importantly the socialists ones (above all the Soviet one), which in its last phase (of Cold War) understood International Law "as the sum of norms that are developed upon agreement between States that govern their relations based on confrontation and cooperation between them, and that by expressing the will of their leading classes, are imposed in cases of need, by the pressure of (coercion) applied by States in collective or individual manner" (Korovin, 1963); b)

${ }^{10}$ Telegraphically (Sánchez-Bayón, 2011): a) ius gentium or law of nations has for itself since the Republic until Carcaila’s imperial Constitution of 212, whose conception for the Romans alluded to their relation with the barbarians or foreigners; b) natural law and of nations in modern Christianity to refer to common law between the peoples of humanity (beyond that of former Christianity) - it is not about a law of nations that regulates the interaction between the other or a stranger, but that it aspires to mediate between political communities with a shared sense of justice; that's how it is understood and disseminated by the School of Salamanca up to the Central European iusracionalists, e.g. Grocio, Puffendorf; c) International Law is the Anglo-Saxon neologism, that is born at the time of the codifications and because of this also continues the paradigm of the formalist state positivism; and now; d) (neo)utrumque ius/Global Law, is the neologism mentioned. 
of the subjective type, that is, centred in the regulatory and regulated subjects (put forward especially by Germans and Anglo-Saxons), understanding for International Law "the sum of rules and principles of conduct that bind civilizing States in their mutual relations” (Kelsen, 1961); c) of the procedural type, those preoccupied with the process of elaborating norms (argued principally by Latin American authors), defining International Law as the "sum of norms created by means of the appropriate procedures by two or more States or by the international community, have legal character for their recipients" (Moreno, 1936); d) of the institutional type (originally based in Europe, but later developed in the United States), concentrated in the sources of the discipline, for which reason International Law "is the name given to the sum of norms created through reiterated case law or agreed in treaties and considered legally binding for all the States in their mutual relations" (Oppenheim, 1961); e) the formalist type (advanced by continental Europeans), in such a way that International Law is conceived as "the sum of legal norms that regulate the relations between different subjects of law that form the international community” (González Campos, Sánchez-Rodríguez, 1983) et al.

Thus recapitulating — and redirecting the ample fan of doctrinal definitions - there is way to talk about a formal concept (a sum of valid principles and norms that order international society), material (legal system that regulates international relations), structural (sum of principles and norms that constitute the legal system of the international community in the era of coexistence and cooperation of States that possess different levels of economic and social development, and that in the same way differ in their power, political conceptions and ideology), and functional (International Law should serve to determine the State's competencies, to develop princeples and methods of coordination, to sanction cases in which norms are violated - in contracts as well as in tort cases - and conflict resolution - we clarify a priori that it is not about parcels, but indicators of the direction International Law has at each juncture. However, this still is insufficient for today's demands. This is the reason why we insist in the neologisms (neo)utrumque ius o Global Law-according to the tradition to which one wishes to prioritize. It should be enough to say, to make the point, that if International Law arises from the necessity of articulating a new Law in accordance with the new international society of sovereign States, then, since today the supranational community is changing, once more, a new concept urgently needed. Therefore, we understand for Global Law - preliminary, since we will outline it in the following pages and to the effects of this study concerned with political-juridical systems-the political-juridical system of a democratic and humanist regime of today's western community, based on the foundation and common tools of Law, developed thanks to new information and communication technologies (and promoted through international organizations and the transnational forums of civil society).

b) Foundations (strictu sensu): there are to matters to value, presuppositions and justifications-clarifying how we have passed from the framework of International Law to Global Law. In regard to the presuppositions, International Law does not arise ex nihil (of ideas void of a temporal, place, or subject matter basis). Rather, they come from attempts to order the largest possible human community (the imperial: Hellenic, Roman; the catholic: from the Holy Roman Empire to that of the Spanish Kingdoms); the cosmopolitan: from the Age of Enlightenment to the hatching of the nation-State; the global: in course). Therefore, supranational law-before International Law, today Global Law-is based on the changes occurred in our community of universal vocation (for civilized humanity: ekumene, Christianity, the West), for which reason to determine it, in its corresponding juncture today, it becomes necessary to resort to sociological presuppositions-something that was clear even to the members of the positivist school of the Vienna Circle, from which hail authors such as Kelsen or Verdross, and whose fervent followers seem to have forgotten. Thus, Global Law is itself a requirement of the impact of globalization in the Western community. To better know it and to be able to offer the best possible order, one must first consider such sociological presuppositions, which clarify the necessary changes at a paradigmatic and methodological level, etc. In regard to the justification of International Law responds to theories of diverse order: a) subjective theories (or voluntary), by which International law depends on States' consent, as much as selflimitation postulated by Hegel and Jellinek (the States bind themselves according to their interests and needs), as much as common will defended by Triepel and Anzilotti (International Law is not the result of States' consent, but their consent on the rules of coexistence-difference which allows advancing the recognition of international jurisprudence); among other subjective habitual theories, there remains to mention the one of the delegation of internal/domestic Law of Wenzel, Lasson, and Kauffmann (International Law is recognized and incorporated into domestic law, and then it is applied not so much because of it, but for its integration - thesis also held by Constitutionalist European Continentals). b) Objectivist theories, as the positivist norm of the pre-existing or original norm, sustained since Gentili until Kelsen (International Law finds its grounding in international 
customs); that of classic Natural Law of the School of Salamanca and the Rational Law of the Central Europeans (International Law is based on Natural Law); and modern natural law of Reuter, Walzer, etc. (International Law based in universal and permanent principles and values).

Certainly, International Law's juridical problems of recognition ${ }^{11}$ are not because of its conditio ordinatio rationis-because it is not any other philosophy or ideology, nor a mere courtesy or comitas gentium, but just one more juridical science; as a consequence, the juridical weakness of International Law is not because of its difficulties, but in the constant changes in international society - today the World community. And it is that, rather than attempting to patch up International Law, concerned with binding relationships between States, and constructed from an outdated paradigm of formal positivism, which favours unequal exchanges, it is now time to think of new paradigm in accordance with globalization (where operates a legal network of regulatory networks).

In regard to the principles of Global Law, which operate as groundings, we remit to what we have already discussed.

c) Features and elements-groundings to analyze the juridical nature: International Law is born as an aspiration to articulate a primary legal system (original and autonomous), based on a balanced yet not equal standing between subjects, except when legally speaking, and still in this case primacy is bestowed to States and, among these, to the western superpowers; with an unequal distribution of power, with diverse focal points and disparate organisms, which supposes the absence of a central legislating organ, the absence of an automatically binding jurisdictional institution. States are free to choose the most adequate means of dispute resolution. Thus, this is a duty of means, that is, a sort of voluntary jurisdiction, because one needs the acquiescence of all affected parties in the organization before dealing with the matter; with the failure of an executive administration, especially, in matters regarding State sanctioning, with except to arts. 42 \& 94 cases of the UN Charter, in which the Security Council is authorized to use force in the case that peace is in danger, as well as there where the world's public opinion is persuaded; etc. The apparently scarce features of International Law, if compared to domestic or National Law, are not such, but rather another example that we are dealing with a Law that is in constant change, because it's underlying social reality is also in permanent flux. In that process it is crucial that Law does not separate from rationality/reasonableness or auctoritas to avoid its fall into the dangerous path of potestas or coercive force. That is the objective of Global Law, whose dominant features are flexibility to systematize-because it is a type of integrating Law, and the richness of its elements (in range as in depth). In regard to the depth of its features and elements, such an issue is the responsibility of the study of the Law of International Organizations. However, as to the primacy almost exclusive and excluding that International Law confers to States, be it enough to say that Global Law advocates the recognition of legal capacity in international relations to other actors: international organizations, individuals, minorities, peoples, movements of national liberation, belligerent groups, and, lately, even transnational forces such as multinational enterprises and religious groups. In regard to the object (supranational reality and its order), we have sufficiently clarified that in regard to the $18^{\text {th }}$ century enlightened model and its International Law of State conferences, today we think more along the lines of a global village ${ }^{12}$ and its corresponding regulations. And with regard to the contents (rights and duties, in addition to the material and temporal terms), Global Law is open to recognizing the rights and duties that arise within the supranational community, as the classic acquired rights already are, that reference to other sources, such as international customs and principles.

d) Sources (discussed above) —now, as an example of the network of regulatory networks of globalization and its treatment as a holistic system, references RIDE.

e) Object and themes: due to the deviation of the object of study and International Law's themes, ever more fragmented and confused, since Public International Law seems only to be concerned with sovereignty in the

\footnotetext{
${ }^{11}$ Traditionally, the following problems (or concomitant difficulties, causing legal conflicts) have been pointed at: tension between structural principles of International Law and the General Principles of Law: subjective relativity (e.g., there are many characters of International Law: international, regional, sector, multilateral, bilateral, particular, or inter parties; International Law and its Common Law and conventional norms against third States or a State's will); doubtful binding or plenary power (International Law can be dispositive or imperative, and at the same time ius gentium and erga omnes, or not; International Law depends on consent and consensus between States; legal loopholes, jurisdiction, and sanction difficulties; difficulty of codifying International Law (because of the complex relationship between customs and treaties, besides the inherent difficulty of approving a Code-its processing is slow and is disliked by the Anglo-Saxon world, since they are more inductive); inadequate recognition of eventualities (e.g., themes such as terrorism and the environment, actors turned into subjects, etc.); the perennial crisis (International Law does not stop from mutating in its creation and application, and it fails to follow a clear evolutionary or regressive pattern; and this is because International Law must resolve the crises of the international community, more than its own as a legal order and system).

${ }^{12}$ Other recurring metaphors—already mentioned—are global Las Vegas, global companies, etc.; Sánchez-Bayón, 2012, 2013.
} 
relationship between States, surprisingly failing to consider International Relations, due to agreements on how to distribute department chairs, and Private International Law shows a profound denaturalization, because a chunk of its cultivators reject even the features of its denomination, and the others who still respect part of the tradition, are only interested in the order of that which is foreign in national Law. Therefore, who studies today what is truly international, that which concerns the entire world community? and who is concerned with in ordering la nova lex mercatoria of particular sources that operate across borders? From these pages we propose recovering the international themes (traditional or primary, e.g. international relations: diplomacy; commerce and war; international spaces: the sea and the poles), combining them with the transnational (transitory, e.g., outer space, cooperation, and development, International Criminal Law) and, above all, opening up to global themes (coming after or derived, e.g., human rights, self-determination, terrorism, environment). In regard to the content, we also make an invitation to consider creating a system to ensure a fair social order for humanity, without forgetting soft-law proposals and related issues such as e-Government, democratic law and governability and Global civics, in order to deepen in the study of concrete and difficult cases.

\section{Evaluation: Quo vadis ius gentium?13}

From the word and tradition of the Romans and Canonist (and their later specialties as iusnaturalistas) the mos hispanicus of the legal commentators is nurtured (the ones who have given impulse to the ratio iuris and to usus modernus), in that way planting the seed to the modern Law of People/International Law, concerned with the study of: a) themes such as iure belli, pacis, indis et commercio [of the law of war, peace, indigenous and commerce] (School of Salamanca or Hispanic legal commentary, from Vitoria to Suarez); b) issues such as mare liberum v. dominio maris [maritime liberty opposed to maritime dominance] (Central-European Schools, Dutch, from Grocio to Thomasius, as much as German ones, from Rachel to Martens); c) the matter of ius humanae societas [law of human society] (Anglo-Saxon Schools, from Hobbes to Locke-and their projection to the Federalists-in addition to the Italian Schools, with Lampredi or Alighieri). The natural law, yet positivist ${ }^{14}$, commentators are followed by $18^{\text {th }}$ Century legal commentators on philosophy, concerned with the international order and the consolidation of peace, in cases described even as perpetual peace. ${ }^{15}$ One can distinguish the analytic and metaphysical influence of Kant and Hegel-although the latter one seemed more inclined to favour an external State Law: sovereignty, borders, war, diplomacy, etc.- -in the system to follow by the earlier writers and promoters of making public and available for learning the rich material thought out for the constitution of the departments of International Law and their course of study (and Comparative Public Law - promoter of federalism), from the pan-European Germans (in the universities of Heidelberg, Berlin, and Leipzig, above all): Klüber, Schmalz, Saalfeld, Heffter, etc.; up to the Austrians heirs to the Circle of Vienna (and their scientism, in the style of the booming Natural Sciences), obsessed with the incipient formalist positivism, such as Kunz, Kelsen, Jellinek, Verdross, Zemanek, etc. In regard to the French and Italian authors ${ }^{16}$, they do not lend much attention to International Law, until they begin their respective colonial adventures-to legitimate-towards the end of the $19^{\text {th }}$ Century. With regard to the British, as a maritime empire, they become the great promoters of International Law departments and courses of study, but of the private type, since their principal concern was guaranteeing international navigation and to give protection to their companies businesses ${ }^{17}$. Lastly, we cannot fail to

\footnotetext{
${ }^{13}$ To know a little bit more about the scientific History of International Law—as my masters—it refers the readings by Prof. Truyol y Serra (Universities of Madrid, Lisbon, La Laguna and Murcia), and D. Kennedy (Brown \& Harvard University). Also, the beginning studies are founded in the School of Salamanca, and the review of authors as Von Ompteda (whose work was continued by Von Kamptz and Ward).

${ }^{14}$ Natural Law and the Law of Peoples, applied to interstate relations, is positive Law, because it lies on communis consensus gentium [common consent of peoples], giving place to a ius gentium voluntarium - Law is not abided because of the fear to the force that backs it, but by persuading that it is what is correct, most adequate. It is because of this that, instead of war, good offices are ever more promoted (e.g Diplomacy and mechanisms of alternate dispute resolution).

${ }^{15}$ Cosmopolitan proposals for peace: Llull (Liber de fine, 1305, and Liber de acquisitione Térrea Sanctae, 1309) Dubois (De Recuperatione Térrea Sanctae, 1306), Comenius/Komensky (Panergesia, 1666), W. Penn (Essay towards the Present and Future Peace of Europe, 1693) Castel/Abad de Saint-Pierre (Abrégé du projet de paix perpétuelle, 1728), Rousseau (Jugement sur la paix perpétuelle, 1761), Kant (Zum ewigen frieden, 1795), Bentham (Project for a perpetual peace, 1789).

${ }^{16}$ French contributions: Fauchille, Pillet, and Pradelle (University of Paris), with the foundation of the journal Revue Générale de Droit International Public, and the Institute of International High Studies; Bonfils' textbook (who was the Dean of the Law School—University of Toulosse). Italian contributions: the caller School of International Law (for Public \& Private International, in a comparative view), with Professors as Casanova, Mancini, Pertile, Olivi et al.

${ }^{17}$ According to Austin’s analytical positivism: Amos, 1872, 1874; Holland, 1872, 1898; Hall, 1880, 1894; Oppenheim, 1906; West-Lake, 1907, etc.
} 
mention American authors (many of their pioneers were at the same time professors, magistrates, and great statesmen $)^{18}$, really interested and precociously concerned by International Law-in tension with Constitutional Law, to provide their federalism with a good legal foundation ${ }^{19}$. To understand the recent scientific revolution of International Law it is necessary to pay attention to antagonistic crowing between internationalists of Columbia Univ. (e.g., Jenkin, Schachter) and Yale (e.g., Laswell, Myres, McDougal, Reisman): before the Second World War, Yale represented the principal trend, of a positivist cut (functionalist and organicist), while Columbia was the naturalist law counterpoint. After the $2^{\text {nd }}$ World War, the roles become reversed, and Columbia passes to lead formalist positivism (normativist and opposed to soft law), opposed to Yale's anti-formalist, much more bent on real international politics (or International Relations) ${ }^{20}$. The definite split between International Law and International Relations was a result of the fall of the Union of Soviet Socialist Republics (URSS)—not of its ideology and its intellectual sway - and with the trend of thought named the end of History (from Bell to Fukuyama), since it was thought that what was only left was technological development, leaving without defence the ends and values of humanity and the World, and completely at the mercy of a relativity that was difficult to answer and without solid basis. From there that, a good part of Continental Europe, International Law is today studied only from the paradigm of formalist positivism - a regression of foreign State Law, where the subjective vision is excluded from Law. In Spain, with the university reforms in the 1980's decade, International Law, as an heir of humanist law of a political-juridical culture of the School of Salamanca, is abandoned, passing through the Real Studies of San Isidro, until the Institute of Human Rights-Univ. Complutense (in its first period). Its academic trajectory is also forgotten, from its emancipation from History and Philosophy of Civil and Canon Law, and its consolidation in the courses of studies at the end of the $19^{\text {th }}$ Century, point at which the first modern textbooks appear, such as the Torres Campos, Acosta, Labra, Fdez. Prida et al. Interesting enough, it is how the mentioned cultural heritage and its rich tradition were lost, specially, because the premature pass away of two great professors, who reformed the discipline: Trias de Bes (Univ. Barcelona, 1965) and Luna García (Univ. Madrid, 1967); also for the exile of their disciples to other emerging areas: Prof. Truyol y Serra (Moral \& Political Sciences Dpt.-UCM). In this way, the discipline is left without a guide and at the mercy of the bureaucratic meddling — sending it down the reductionist path of formalist positivism and its technicalities, against which there was a certain resistance from great professors, such as Aguilar Navarro (being one of his celebrated disciples the already mentioned Prof. Carrillo Salcedo), but which after the great purges of 1965-during the dictatorship—finally, started yielding.

\section{Law (and Politics) of International Organizations: A Remedy against Formal Positivism?}

As we have reiterated, we live in a world in crisis: a change of century and millennium, with the blurring of tangible limits and the articulation of virtual networks in a globalized world of liquid societies of risk, etc. We are talking about the rupture prior to the transit, since, depending on how it is dealt with, so will be the result: a) an evolution toward the global knowledge society (type I civilization); or b) an involution to a new stage of force, a discursive violence that ends creating a greater social fragmentation and very possibly an armed conflict. Keep in mind that the modern origin of international organizations (lato sensu) proceeds from the decomposition of the European imperial order, which was substituted by the State order created after the Peace of Westphalia, based on diplomatic alliances to which other mechanisms of coexistence and progressive coordination, such as consulting systems, conferences, etc. Almost two centuries later (after having overcome the age of empires and the ancient regime, and in the process of consolidation of the age of Law and the New Regime) appear the first international organizations, evermore autonomous and tending to an administration-thus their denomination, international institutions — of interdependent solidarity of the world community. The problem lies in the chip-

${ }^{18}$ Here we can mention as examples Kent, Holmes, Story, etc., and above all, President Wilson.

${ }^{19}$ The tensions about the federalist project between internationalists and constitutionalists thinkers did not end even after the approval of the Constitution (1789) and the Declaration of Rights (1791). The discussion between Calhoun (he advocates of the international thesis, based on the State veto against federal regulation: art. V and the 10th Amendment), and Webster (he advocates of the constitutional thesis, based on federal integration, for which reason it regulation should prevail: the Preamble and art. IV). The matter was not resolved until after the Civil War and the passing of the 14th Amendment, where it became clear that the federal projects are not the matter of international organization (Sánchez-Bayón, 2008-13, 2012a).

${ }^{20}$ This is how we explain Morgenthau going adrift and his school as well as the later apparition of the transnational law such as Aliot, Berman, Carty, Charlesworth, Chimni, Chinkin, Ingle, Frankenberg, Hernández, Kaskennierni, Lanbille, Mutua, Paul, et al.; or the interdisciplinary generation of Álvarez, the Kennedys, Kingsbury, Koh, Teson, etc., and the humanist law such as Falk, Mendlavitz, etc. (Sánchez-Bayón, 2011a, 2011b). 
ping away of the consolidation of the age of Law, since cyclically there has been a tendency of considering force and law as equivalent-paying more attention to the technique of coercion than to authority through a sound rationale or reasoning, becoming into some type of devastating armed conflict; in this way one can distinguish diverse stages (in their apparent ptolomeic retrograde motion): a) Concert of nations: after the Napoleonic Wars, with the Congress of Vienna of 1815 a stage of pacific coexistence and incipient commercial collaboration is inaugurated through international conferences, where transnational river commissions were established (e.g., Central Commission for the Navigation on the Rhine of 1815, European Commission of the Danube of 1856) or international administrative unions (e.g., International Telegraphic Union of 1865, Universal Postal Union of 1874); b) International Society: after the First World War, with the Versailles Treaty of 1919 (and the other peace treaties and pacific conflict resolutions, such as the Briand-Kellogg Pact of 1928), initiates an era of more diverse collaboration and completely institutionalized — to the point that we once again have arbitration and an international jurisdiction system is foreseen, such as the Permanent Court of International Justice, all promoted from the Society or League of nations; c) Global Community: after the Second World War, with the United Nations Charter of San Francisco of 1945, and from the UN's platform starts an era of global administration, that is made possible by the new technologies, but with a series of setbacks caused by scattered conflicts, such as the Cold War and the actual War on Terror-giving place to a certain involution, where there is the temptation to once again confuse Law with force, and to submit international organizations to the will of certain States, as a curtain to their geopolitics. Then, at the moment, more than even it is necessary that universities recover their role as communities of inquiry and of rehearsal of formulas for the progress of humanity, where committed citizens with a critical sense are formed - trying to abandon the current loss of direction, of mere standardized centres of training of professional technocrats, because, if not, there will not be any other way:

a) The detection of the black swan ${ }^{21}$ : the new knowledge that we are yet to discover, does not lie so much in the value of international organizations to create networks of interdependent solidarity that re-humanizes, re-socializes and re-democratizes the international order, but rather what is feared is the statist involution because of the terrorist attacks of 9/11, becoming a geopolitics of superpowers, based on an external State Law of formal positivism, very discursive (technical and procedural) and scarcely realistic (substantive). Such an involution would suppose the already mentioned confusion of Law with power, and this with force, until the false reduction that the law of the strongest is reached, giving place to a growing planetary fragmentation (because of the double standard and the petty conceptual solidity of an International Law excessively automatic), with which in the end the field would be sown for new armed conflicts.

b) The enunciation of a global legal theory of international organizations: if we recover the fundamentals, a theory such as this is not only possible, but is also urgent and necessary to reintroduce a minimal order and legal security, moreover if we continue under the formalist State positivism-we must abandon the technique of winging it, the ultra vires corrections and the political opportunity criteria to re-establish some intellectual hygiene in regard to it. For which reason it is essential to reintegrated the study of objective Law (principles and norms) with substantive Law (interests and legal relations), as well as Law in regard to its form (validity analysis and legal nature) and according to its purpose or end (analysis of intention and levels of justice). Equally, it is convenient to reconnect International Law with similar disciplines with which it shared a very close relationship before the deviation occurred during the Cold War.

As a restructuring discipline, the Law of International Organizations, we find its precedent in the courses of studies of Natural Law and of the Law of Peoples, just as we can corroborate up to the age of Restoration (see Holy Alliance Treaty of 1815: "In the name of the holy and indivisible Trinity (...) of the benefits that divine providence has wanted to bestow on States whose governments are under our confidence (...)"). During the $19^{\text {th }}$ century, the Philosophy of Law and International Law go hand in hand, having an effect on the phenomenon of the evolution of international organizations (see the Covenant of the League of Nations of 1919-and its amendment in the Kellogg-Briand Pact of 1928: "the High Contracting Parties consider/declare (...)"). More recently, before the deviation to a denaturalizing formalist positivism of International Law-reducing it to a materialism of principles and norms of foreign State Law or of a transnational Law of superpowers, closer to the exhibition of force than to reason, in the decades of 1940 and 1950, the study of the Law of International Or-

${ }^{21}$ The black swan is a warning call against the absolutes (of thinking that all swans were white, when Australia was discovered, we also discovered that swans could be black), for which reason this metaphor, represents the fragility of knowledge, ever more vulnerable, when it is not based in analytical or empirical proposals, but of formalists of the ideal type and technocratic lectures, insisting on studying only that which we already know and totally closing itself off from the perception of new possibilities. Therefore, the black swan represents that happening that breaks with the current paradigm, opening new doors to the perception of reality. 
ganizations is based in the interaction of International Law with Comparative Law, without losing sight of International Relations (see UN Charter: "We the peoples of the United Nations determined (...)"). Only in the decade of 1990, with the fall of the USSR, which was prone to instrumentally using international organizations as State toys, for the advanced party of the revolution, as well as with the surge of new technologies, then, there seems to resurge the betrayed justifications, supported by the media for their materialization... until the start of the War on Terror, which cause legal technicalities such as preventive legitimate defence-void of any legal logic and leading to the confusing fear of Law with regulation by force. In the United States, the interdisciplinary drive of the study of the Law of International Organizations-incorporating it in this way as a course offering — was possible (almost for fifteen years) thanks to - the previously mentioned NAIL movement, backed by International Law Scholars (and some comparative law scholar) at universities such as Harvard, Tufts, Northwestern, Connecticut, Wisconsin, etc. In Spain, as well, the incorporation of the study of the Law of International Organizations took place in the 1960s decade, in the Political Science and Sociology School at Univ. Complutense (in its Law and International Relations Dpt.), with the course on "International Administrative and Political Organization” (in charge of-consecutively_Prof. Truyol y Serra, Medina, Burgos). Three decades later, after the previously mentioned 1980s university reform, the Law of International Organizations also begins to gain interest, starting with the Univ. Carlos III (Public International Law Dpt.), with the course "International Organization (United Nations and Specialized Organisms)" (in charge of Prof. Castro-Rial, Fdez. Liesa, and Mariño), as well as the UNED-International Law Area (in charge of Prof. Palomares, García, Picazo, etc.) —and my case at ICADE-UPCO and UCJC, also at DePaul.

\section{Conclusion}

It is difficult to conclude something that is in progress, in full flux. However, it is important to remember the following key-ideas: a) the World is changing, for which reason our perception of it must also change- that is, the necessity and the urgency of rethinking the paradigm with which we conceive and deal with it; b) the Schools of Law (from late $19^{\text {th }}$ Century), they must be extinguished, where they have been teaching (under the State formal positivism paradigm), to the following generations of expert lawyers or lawyers/solicitors-and not of legal scholars - to apply a regulation whose monopoly has been left in the hands of the State, and this has produced a sort of juridical mercantilist in the international ambit, where the order of the civilized world has been reduced to the game of interests and rules of the great powers. Then, with the new School of Legal and Social Sciences, it is offered a more-realistic paradigm, besides one systematic and fuzzy, where students do not memorize empty content, but where they learn to be operators of a complex social reality of glocal reach; c) the Global Law should not be born in the offices of the great academic scholars looking for a general theory, but from the shared experience of all—if not, International Law will lack the sufficient legitimacy, validity, and efficacy to guarantee its continuity, and above all, peace and prosperity between nations - in the Latin sense: peoples/nations; ergo, without even having time to think of new cosmopolitan editions, as the often cited knowledge society.

\section{References ${ }^{22}$}

Acosta, L. G. (1908). Curso elemental de Derecho Internacional Público e Historia de los Tratados. Valencia: Private Edition.

Amos, S. (1872). Systematic view of the Science of Jurisprudence. London: Private Edition.

Amos, S. (1874). Lectures on International Law. London: Private Edition.

Bentham, J. (1780). Introduction to the Principles of Morals and Legislation. London: Private Edition.

Bentham, J. (1789). Project for a Perpetual Peace. London: Private Edition.

Bonfils, H. (1910). Traité de Droit International Public. Paris: Private Edition.

Bush, G. (1990). The UN: World Parliament of Peace. Washington DC: US Department of State. Toward a New World Order. Washington DC: US Department of State.

Carrillo Salcedo, J. A. (1991). El Derecho Internacional en perspectiva histórica. Madrid: Tecnos.

\footnotetext{
${ }^{22}$ The quotations and the development of ideas exposed here, they are included in Sánchez-Bayón publications (cited here, and written as a researcher at ELLSP-DePaul, LAS-Baylor, Dpto. Historia del Derecho-UNED, etc.), and the origins in Zalacaín: Harvard Journal of Latin America - under the direction of Sánchez-Rivera (and edition of Sánchez-Bayón), 2002-2003, and its opening-up to Ibero-America.
} 
Casanova, L. (1876). Lezioni di Diritto Pubblico Internazionale. Florence.

Domingo, R. (2008). ¿Qué es el Derecho Global? Aranzadi: Thomson Reuters.

Guariglia, O. (2010). En camino de una justicia global. Madrid: Marcial Pons.

Hall, W. (1880). A Treatise on International Law. Oxford: Private Edition.

Hall, W. (1894). A Treatise on the Foreign Powers and Jurisdiction of the British Crown. Oxford: Private Edition.

Heffter, A. (1844). Das Europäische Völkerrecht der Gegenwart auf den bisherigen Grundlagen. Berlin: Private Edition.

Holland, T. (1898). Studies in International Law. Oxford: Private Edition.

Klüber, J. (1821). Das moderne Europäische Völkerrech. Heidelberg: Private Edition.

Labra, R. (1905). El Derecho Internacional en España. Madrid: Private edition.

Labra, R. (1907). Estudios de Derecho Internacional Público. Madrid: Private edition.

Mancini, P. (1873). Diritto Internazionale. Turín: Private Edition.

Nussbaum, A. (1947). A Concise History of the Law of Nations. New York: MacMillan Co.

Oppenheim, L. (1906). International Law. A Treatise. London: Private Edition.

Pureza, J.M. (2002): El patrimonio común de la humanidad ¿Hacia un Derecho Internacional de la solidaridad? Madrid: Editorial Trotta.

Riquelme, R. (2005). Derecho internacional. Entre un orden global y fragmentado. Madrid: Editorial Biblioteca Nueva.

Saalfeld, F. (1833). Handbuch des positivem Völkerrechts. Tubinga: Private Edition.

Sánchez-Bayón, A. (2008-13). La Modernidad sin prejuicios. Madrid.

Sánchez-Bayón, A. (2009). Estudios de cultura político-jurídica. Madrid: Delta.

Sánchez-Bayón, A. (2011a). Introducción al Derecho Comparado y Global. Madrid: Delta.

Sánchez-Bayón, A. (2011b). Sistema de Derecho Comparado y Global. Valencia: Tirant Lo Blanch.

Sánchez-Bayón, A. (2012a). Estado y religión de acuerdo con los EE.UU. Saarbrücken: EAE.

Sánchez-Bayón, A. (2012b). Humanismo Iberoamericano. Guatemala: Cara Parens.

Sánchez-Bayón, A. (2012c). Filosofía Político-Jurídica Glocal. Saarbrücken: EAE.

Sánchez-Bayón, A. (2013). Renovación de la Filosofía Social Iberoamericana. Valencia: Tirant Lo Blanch.

Stadtmüller, G. (1951). Geschichte des Völkerrechts. Hannover: Hermann Schroedel Verlag.

Torres Campos, M. (1890). Elementos de Derecho Internacional. Madrid.

Truyol y Serra, A. (1974). Sociedad Internacional, Madrid: Alianza. 
Scientific Research Publishing (SCIRP) is one of the largest Open Access journal publishers. It is currently publishing more than 200 open access, online, peer-reviewed journals covering a wide range of academic disciplines. SCIRP serves the worldwide academic communities and contributes to the progress and application of science with its publication.

Other selected journals from SCIRP are listed as below. Submit your manuscript to us via either submit@scirp.org or Online Submission Portal.
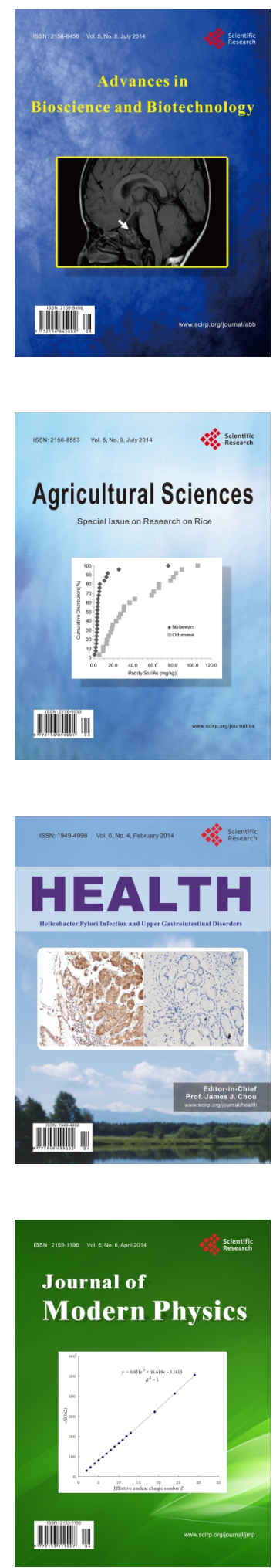
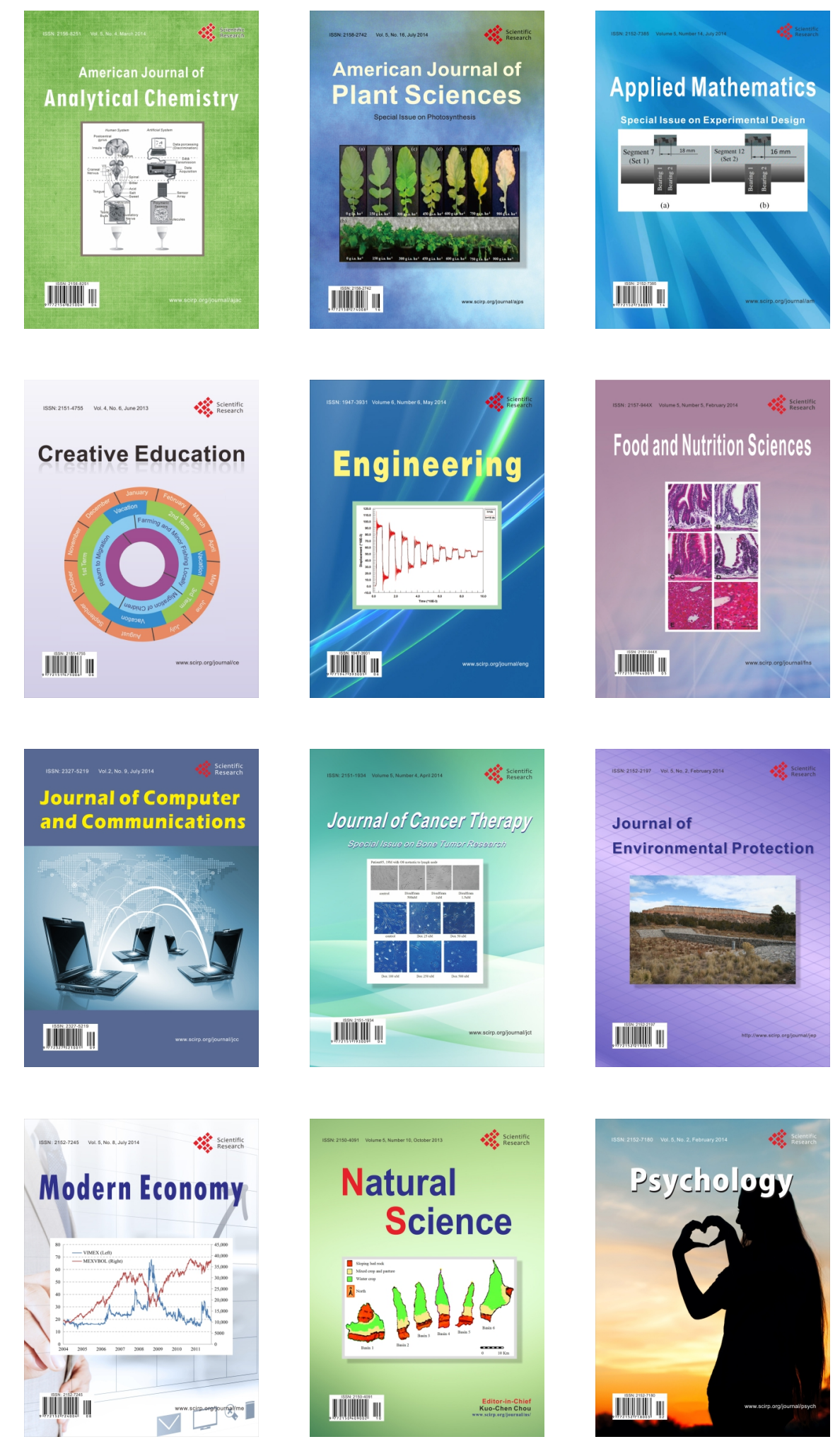